\title{
The Social Production of Invited Spaces: Toward an Understanding of the Invitational Character of Spaces for Citizens' Initiatives
}

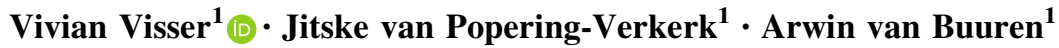

Accepted: 19 December 2020/Published online: 19 January 2021

(C) The Author(s) 2021

\begin{abstract}
The rise of citizens' initiatives is changing the relation between governments and citizens. This paper contributes to the discussion of how governments can productively relate to these self-organizing citizens. The study analyzes the relation between the social production of invited spaces and the invitational character of such spaces, as perceived by governments and citizens. Invited spaces are the (institutional, legal, organizational, political and policy) spaces that are created by governments for citizens to take on initiatives to create public value. We characterize four types of invited spaces and compare four cases in Dutch planning to analyze how these types of invited spaces are perceived as invitational. From the analysis, we draw specific lessons for governments that want to stimulate citizens' initiatives. We conclude with a general insight for public administration scholars; in addition to formal rules and structures, scholars should pay more attention to interactions, attitudes and meaning making of both government officials and citizens.
\end{abstract}

Keywords Citizens' initiatives · Invited space - Selforganization $\cdot$ Invitational governance

Vivian Visser

visser@essb.eur.nl

Jitske van Popering-Verkerk

vanpopering@erbs.eur.nl

Arwin van Buuren

vanbuuren@essb.eur.nl

1 Department of Public Administration and Sociology, Erasmus University Rotterdam, P.O. Box 1738, 3000 DR Rotterdam, The Netherlands

\section{Introduction}

Today, we are witnessing a rise of citizens who organize themselves to create public value (e.g., Aiken and Taylor 2019). Citizens deliberate on the values that are important for "the public" (Meynhardt 2009) and realize these values by self-organization. Over the past century, we can see a shift from provider-centric (supply-driven) traditional public administration-in which the government took care of public service delivery-via the more market-oriented New Public Management-aimed at enhancing efficiency through public-private competition-to Public Value Governance-in which citizens become co-creators of public value (Bovaird 2007; Bryson et al. 2014; Stoker 2006). The next phase in this evolution, commencing in this day and age, is that self-organizing citizens take over public service delivery (Dekker 2019; Eriksson 2012).

On the one hand, we can understand this development as a reaction of governments who acknowledge they cannot solve contemporary wicked problems alone and increasingly call on citizens to use their resources and skills to deal with these challenges (Kooiman 1999). On the other hand, citizens have less trust in "traditional" institutions of representative democracy (Bang 2009) and take matters into their own hands because they believe they can do better (Gofen 2015). Moreover, the expansion of citizens' self-organization is said to be a response to a retreating neoliberal state that welcomes citizens' public service delivery because it is supposedly cheaper (Ghose 2005; Korstenbroek and Smets 2019; Rosol 2012).

One of these emerging structures of self-organized collective action has the form of citizens' or community-based initiatives (CIs). These are forms of community engagement in which citizens collectively mobilize capacities and resources to define and carry out actions aimed at providing 
public goods or services for their community (Duijn et al. 2019): for instance, citizens who maintain the playground in their street or citizens who start a community center and organize elderly care in this center. CIs are essentially selforganized and, in its core, independent from the government organizations (Bakker et al. 2012).

However, this form of self-organization does not take place in a vacuum. In fact, it often evolves in the shadow of hierarchy (Nederhand et al. 2016). As a response to the increased self-organization of citizens, governments deploy various strategies. One of these strategies is to actively stimulate citizens to take on initiatives by creating invited spaces (Cornwall 2004), (institutional, legal, organizational, political and policy) spaces that are created by governments for citizens to take on initiatives to create public value. Thus, the governmental goal of creating invited spaces is to stimulate, invite and incite the selforganizing capacity in society. This style of governing is what is elsewhere called "invitational governance" (Van Buuren 2017). Invitational governance differs from other modes like "interactive governance" or "public value governance" because it places the responsibility for public value creation chiefly in the hands of self-organizing citizens. By creating invited spaces, governments invite citizens not just to join a dialogue about or to participate in public value creation, but to take the lead to collectively initiate initiatives to create public value themselves (Igalla et al. 2020).

Numerous studies are conducted about CIs and their relations and interactions with governments (e.g., Igalla et al. 2019; Nederhand et al. 2016). In these studies, the invited space in which these interactions occur is taken for granted. But as Lefebvre (1991) reminds us, every spaceand thus also the invited space-is socially produced: "Space is a social product... it is not simply "there", a neutral container waiting to be filled, but is a dynamic, humanly constructed means of control and hence of domination and of power." It matters how (invited) spaces are produced and bounded; this outcome of social processes influences what actions are to occur within the space, enabling some and blocking others (Cornwall 2002).

Therefore, in this study we focus on the production of the invited spaces and how this relates to the perceived invitational character of the invited spaces, i.e., the (perceived) potential to prompt CIs, as experienced by both government officials and citizens. Based on the literature about invited spaces, self-organization, coproduction and CIs, we concentrate on two dimensions: is the invited space top-down formulated by the government or in collaboration with citizens (the process dimension); and is the invited space for CIs restricted to specific tasks or policy domains or more holistic (the nature dimension). Using four case studies of different types of invited spaces, we aim to examine how the production process and nature of invited spaces influence their perceived invitational character.

In the next section, we elaborate from theory the two dimensions of invited spaces (nature and process). In the third section, we explain the case selection, applied methods and we introduce the cases. In the fourth section, we present the analysis in which we compare the four cases on the two dimensions of invited spaces. We end the paper with our conclusions and our contribution to theories on CIs and invited spaces.

\section{Theoretical Framework}

\section{Invited Spaces and Their Production}

Invited spaces result from a social process of production (Cornwall 2002; Lefebvre 1991). Governments can set the "rules of the game" to demarcate the invited space, i.e., to design the institutional setting in which self-organization must take place (Jones 2003): for instance, rules about who could start a CIs, the kind of public services citizens could take over or the kind of process in which decisions on supporting a CIs are taken (Barnes et al. 2004; Kiser 1984). Citizens may, to a varying extend, negotiate or coproduce these rules (Bovaird 2007). The outcomes of these interactions influence the ultimate invited space. Thus, the production of the invited space must be seen as a social process, in which governments and citizens interact, exert power and play different roles.

\section{The Process of the Production of Invited Spaces: Collaborative Versus Top-Down}

In the literature on CIs, we find various indications that the process of production of the invited space affects the successfulness of invoking citizens' self-organization. Various authors argue that collaboratively producing the invited space benefits the activation of CIs. Particularly from a social constructionist perspective-in which the invited space is seen as an ongoing process of interpreting and interacting - coming to a shared understanding or mutual agreement on this invited space is of utmost importance (Barnes et al. 2004; Lowndes and Sullivan 2008). People will only enter the space when they recognize it as legitimate, open and welcoming. This calls for a deliberative process of determining the boundaries of the invited space in co-creation (Barnes et al. 2004; Bovaird 2007).

More specifically, Rosol (2012) and Kewes and Munsch (2019) show that a feeling of self-determination by initiators is crucial in their decision to commit to a CIs or not. This feeling can only be brought forth when initiators are given the possibility to determine the manner and extent of 
their commitment and work. The openness of the process is an important factor in this. In other words, citizens are only expected to self-organize in initiatives when they themselves can have a say in defining the space in which they are invited. Moreover, Bovaird (2007) theorizes that a collaborative process can lead to broader societal support for the "rules of the game," then when it is formulated topdown. Broader support will more likely invoke societal initiative.

In contrast to the authors mentioned above, other scholars allude to the value of the top-down imposition of rules that demarcate the invited space. One line of reasoning focusses on the productive power of resistance. Cornwall (2004) observes that citizens' self-organization in CIs does not so much arise on invitation by the government, but in resistance from the outside toward the government. This calls attention to the mobilizing power of disagreement, as opposed to agreed judgment via deliberative processes. In a similar vein, Taylor (2007) and Specht (2012) underscore the productive mobilizing power of "outsiders."

Another line of reasoning in favor of unilaterally producing invited spaces comes from literature on self-organization. Different studies show that a disruption or trigger from the outside-i.e., from the government-can be productive in inciting citizens' self-organization. In this case, governments can provide an intended, external incentive for self-organization in CIs. As Kiser (1984) and Voorberg, Bekkers and Tummers (2015) emphasize, topdown imposed boundary rules can encourage citizens to self-organize in CIs. These rules, controls and sanctions can, for example, ensure a fair process for CIs, a dismissal of free riders and a fair use of the public services delivered by CIs. In this way, a top-down production of the invited space can be stimulating (Alford 2002).

So, from the literature, we can conclude that the process of production is an important factor that influences the (perceived) invitational character of invited spaces, but there are different expectations when it comes to the importance of co-defining this space between government and citizens.

\section{The Nature of Invited Spaces: Integrated Versus Fragmented}

In a study on Dutch water management, Duijn and Van Popering-Verkerk (2019) conclude that different values are recombined in community initiatives. This integration of different values is understandably since people experience the daily issues they are confronted with as part of their living environment and thus much more holistic, compared to how these issues are approached by public agencies (Bovaird 2007). The integrated nature of community initiatives can also be seen as a societal reaction upon the fragmentation of governments. Frustrations about the limits of the fragmented system form an important trigger for communities to organize their own public services (Aiken 2000).

Starting from the integrated nature of initiatives, we could expect that the invited space should also be integrated. In this case, governments create opportunities for all kind of initiatives, without specifying a specific policy domain or public task (Boonstra and Boelens 2011; Duijn and Van Popering-Verkerk 2019). Integration could even be fostered, for instance by giving more support to CIs with multiple aims or by creating institutional facilities to combine budgets from different domains.

The need for integrated invited spaces is, however, not undisputed. Several scholars conclude that clear demarcations that align CIs with the fragmented government system are needed. In a literature review on coproduction, Voorberg et al. (2015) show that the incentives must be clear about the kind of public services governments want to coproduce and its benefits for initiators (cf. McLennan 2020; Rosol 2012). The importance of fragmentation is also found in studies on administrators' willingness to support CIs. With clear boundaries that fit the fragmented system, it is easier for CIs to adapt their initiative to governmental policies and thus to secure administrative support (Bryer 2009; Nederhand et al. 2016).

In sum, when it comes to the nature of the invited space, there is controversy about the need for integration versus fragmentation. Thus, we need a better understanding of how the nature influences the invitational character of invited spaces.

\section{Four Types of Invited Spaces}

The invited space that is socially produced is thus characterized by a combination of its process and its nature. Combining these two axes results in four types of invited spaces (see Fig. 1):

In this exploratory study, we analyze the invitational character of four different cases from each corner of Fig. 1. We analyzed them from the perspectives of the two main actors: the government and the (potential) initiators of CIs. For (potential) initiators, it is important that they experience a chance-_"provided" by the government-for being an initiator and producer of public services and public values, and also to deliberate with all partners about the quality of these services and about the values at stake (Bovaird 2007; Rosol 2012). Governments also perceive themselves as more or less invitational. Being invitational is expressed, for instance, in the way they stimulate and facilitate CIs and the extent to which they can keep their 


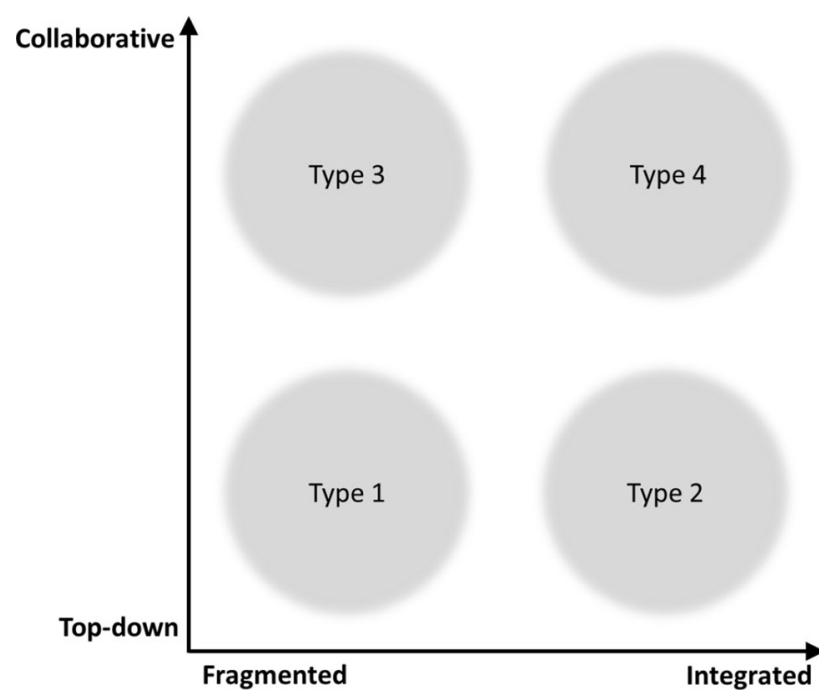

Fig. 1 Four types of invited spaces

hands-off and respect the autonomy of CIs (Nederhand et al. 2016).

Consequently, in our analysis of the different types of invited spaces, we will look at the invitational character with an emphasis on the following broad questions:

- Is the invited space experienced by governments as a space in which CIs are welcomed and facilitated by governments?

- Is the invited space experienced by citizens as a space in which they can organize themselves and take initiative for creating public value in their own way?

The focus on these broad sensitizing questions enables us to more inductively unravel what the invitational character entails for both parties.

\section{Methods and Data}

\section{Method}

Our study uses a multiple case study research approach (Stake 2013). Given the exploratory character of our research, case studies were selected based on theoretical sampling (Eisenhardt 1989), so they were chosen for theoretical reasons to illustrate what happens in each type. To be able to compare the cases, we selected cases that have to do with the spatial domain on a local governmental level (in order to safeguard comparability in terms of more general governance conditions) and that involve programs that are explicitly aimed to prompt CIs, but in a different way, reflecting the different types presented in Fig. 1. For our purpose, the cases differ in the process of production of the invited spaces and in the nature of the resulting invited space. We selected a case for each of the types (see Fig. 2, explained in Sect. 3.2). It is important to mention that we designated for each case a moment in time at which the invited space was initially presented by the local government. At this moment, the invited space was created, and expectations of its invitational character were raised.

Various complementary methods were used to gather the data of the cases: document analysis, (participative) observations, in-depth interviews and focus groups, allowing for triangulation of the data (Flick 2007; Patton 1987; Tellis 1997). "Appendix 1" provides an overview of the data collection for each case. In each case, a minimum of four relevant government officials with different organizational backgrounds were interviewed, varying from councilors to civil servants responsible for policy development or licensing. Moreover, in three cases we observed at least one interactive meeting between citizens and government officials, to further explore the interactions between the main actors of the production of invited spaces and the perceptions of both. The citizens that we interviewed were proposed to us by the involved governmental organization, but were independent from that organization. We selected respondents from extensive lists of potential respondents, and we warranted their anonymity. So the governmental organization would not know who we picked and who said what. Consequently, and as our results will show, respondents felt free to discuss their perspective on the respective governmental organization. We selected citizens who can be characterized as everyday fixers or local heroes (Hendriks and Tops 2005, cf. Bang and Sørensen 1999). These are "active citizens" not affiliated with official civil-society organizations, known to be involved in CIs or interested in starting one.

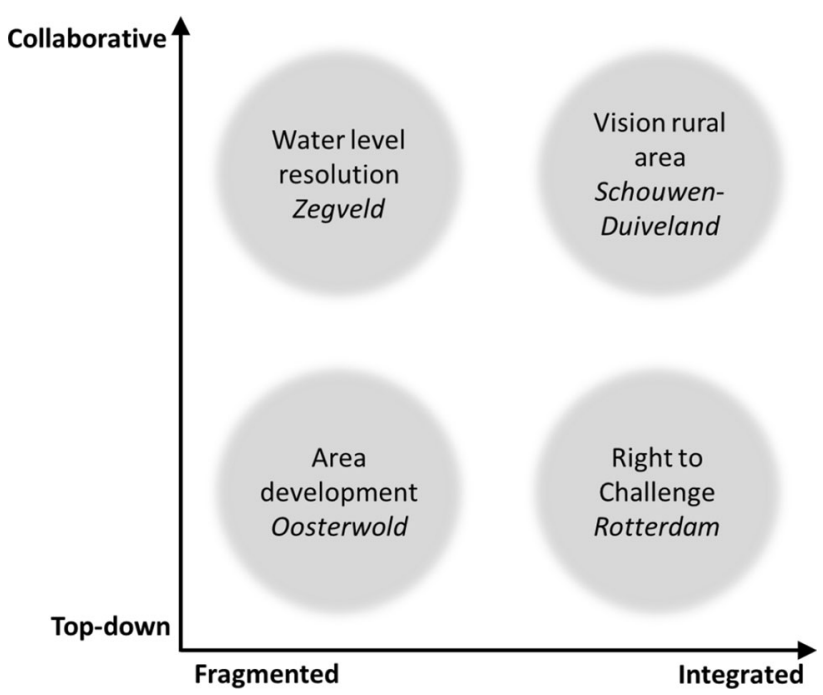

Fig. 2 Cases and their position on the axes of process and nature 
During the interviews, we encouraged respondents to reflect on the invitational character of the invited space that was relevant to them and ensured that the following topics were addressed: their attitudes toward and opinions on CIs, their experiences with and expectations of CIs, the possibilities and barriers they experienced or expected to experience and their perspective on the rules and regulations. Moreover, we asked them to express their general opinions, attitudes and experiences with citizens or governmental agencies. Lastly, we inquired their views on the roles and responsibilities of citizens, governmental agencies and civil servants in reaching policy goals.

We analyzed and coded all documents, transcriptions and reports using constant comparison (Glaser and Strauss 1967). We began with open coding, continued with axial coding and ended with selective coding (Corbin and Strauss 2014). The broad sensitizing questions helped us in coding and understanding the data, finding similarities and differences between cases and developing theory (Blumer 1954). Interview transcripts and reports were checked with respondents, to make sure that we accurately understood their perspective. We translated all quotes presented below from Dutch, and in doing so we tried to reflect the original wording as accurately as possible.

\section{Introduction to the Cases}

\section{Development Residential Area Oosterwold (Top-Down, Fragmented)}

This case concerns the plan for the development of a new residential area of Almere (Flevoland, The Netherlands), named Oosterwold. Oosterwold is an area of about 45 hectares former agricultural land with room for 15,000 residential houses. The municipality aims to create space for bottom-up development with maximum individual freedom for potential residents to develop their own plans. This also means that initiators must take responsibility for their own ('collective') services like water treatment and sanitation, and for public provisions like infrastructure and public green space. Anyone-individuals, groups, professional developers and/or housing associations interested in developing in Oosterworld-is invited to participate.

In this case, we analyzed the first phase of the project (2015-2018) before it became formal policy. To invite residents, the municipality and the water board drew up a scenario and predefined a framework with a limited number of rules, to regulate the future transformation of the area. These top-down, by the governments, determined framework rules discipline the overall development of the area. In general, the framework rules deal with four issues: (i) the choice and the spatial layout of plots, (ii) permitted uses, (iii) the floor area ratio and (iv) the self-reliance of plots (in terms of energy production, sanitation and financial issues) (Cozzolino et al. 2017). For example, all initiators have to realize $50 \%$ urban agriculture on their own lot and $7 \%$ of each lot has to consist of public accessible green. Besides these rules, no additional rules were set, and initiators may realize their own ambitions and plans.

These principles demonstrate the fragmented character of the created invited space, since they only cover one specific domain, which is the spatial-physical domain. As opposed to the examples of integrated invited spaces we will describe below, in this Oosterwold case, initiators are not explicitly invited and stimulated to start initiatives that combine issues in different domains.

\section{Right to Challenge Rotterdam (Top-Down, Integrated)}

Right to Challenge Rotterdam is an instrument of the municipality of Rotterdam to stimulate citizens to take on initiatives. It gives citizens the right to challenge and take over local public tasks, except tasks that are legally reserved for governments (e.g., law enforcement, emergency services). As the councilor happily explained on Twitter: "Rotterdam introduces Right to Challenge, to give power to the citizens of Rotterdam."

Civil servants developed an extended and detailed policy framework, defining the conditions, scope and procedures of CIs qualified to use Right to Challenge (Gemeente Rotterdam 2015, 2016). For example, a challenge is only granted if the budget is equal to the current budget, if the citizens organize themselves in a formal way and if the challenge is supported by the neighborhood. The policy plan also contains a detailed procedure for challenges: citizens propose a challenge; an account manager is appointed; the account manager informs the citizens on the challenged task and the budget available for this task; citizens fill in the online Right to Challenge format; et cetera, until the final decision on the challenge by councilors and a contract with the municipality.

The invited space Right to Challenge Rotterdam is determined by the councilor and the civil servants involved. They use their experiences with citizen initiatives to determine the scope, criteria and procedure of the invited space. Hence, it is a top-down invited space. An important consideration was the integrated nature of initiatives. The City of Rotterdam already had many domain-specific instruments for citizen involvement. Right to Challenge was explicitly presented as an instrument in which a combination of domains, goals and tasks was preferable. We analyzed the experimental pilot phase of the Right to Challenge in 2017. 
Water Level Resolution Zegveld, HDSR (Collaborative, Fragmented)

In the Netherlands, a water level resolution (in Dutch peilbesluit) is a policy instrument of the water boards to decide on the maximum and minimum water levels in lakes and ditches. Water board Stichtse Rijnlanden decided to approach the water level resolution in the small village Zegveld as an invited space, because the water level creates or limits the opportunity for initiatives. For example, higher water levels make room for nature development, while flexible water levels allow for farmers to cultivate certain crops. The water board decided to co-create this invited space together with residents. Residents could voice their interests and ideas at two interactive meetings. The process can be typified as rather socially inclusive. The water board invited all 2,348 residents from Zegveld by postal mail, to come to an open evening to discuss the water level. Over 80 residents showed up, divided between two events and voiced their interests and ideas at the interactive meetings. We-and our respondents with usnoticed that not only the "usual suspects", i.e., farmers, but also "new faces" attended the meetings. In addition to the meetings, a voluntary local sounding board was established. The manager ensured that all interests in the area were well represented, by proactively inviting underrepresented citizens to join the sounding board.

A fundamental decision was made in the organization, to limit the participative process to the given scope of the resolution, i.e., the water level. The resulting invited space is rather narrowly defined. In the final document, we read that "partial revisions" and "individual deviations" from the determined water level are possible. Residents who want to take on initiatives that fit in the fragmented system are invited to ask for permission from the water board.

\section{Environmental Vision Rural Area Schouwen-Duiveland (Collaborative, Integrated)}

Dutch local governments are required to formulate strategic Environmental Visions for their locale, in co-creation with their citizens. The municipality Schouwen-Duiveland decided to "experiment" with writing such a vision for their rural area. The aim of this process was to come to a vision by which stakeholders and citizens feel invited to develop the rural area. Therefore, the municipality decided that the process of writing the vision had to be done in cocreation.

The municipality set up a participative process which can be characterized as moderately socially inclusive (Fung 2006). The team started with interviews with lay stakeholders, known by the civil servants, to delineate the most prominent issues in the area. After that, these issues were clustered and put into an online survey. An invitation to participate in the survey was spread via the local newspaper. In the survey, citizens could voice their view on selected issues. These insights were used in an "area conference" hosted by the municipality. Again, via the local newspaper, citizens were invited to join the conference, which focused on coming to shared ideas to deal with the defined issues. Albeit the "positive vibe" that all participants experienced, the team also acknowledge that the turnout was not that high and consisted mainly of "usual suspects". After the conference, the vision was written down and presented at a public meeting, in which citizens and other stakeholders could voice their opinion. Subsequently, some revisions were made.

Via the participative process and the content of the vision document, the municipality aimed to create a vision by which citizens feel invited to develop concrete initiatives to create public value, as is repeatedly and explicitly mentioned in the document. In particular, initiatives are welcomed that go beyond the spatial domain only and that cleverly combine different issues (Gemeente SchouwenDuiveland 2019). Instead of dealing with the issues in a fragmented way, initiators are stimulated to come up with initiatives that cover multiple (public) domains. For example, an initiative that tackles the issues of an aging population and consequences of climate change simultaneously. We studied this process until the vision was written (2018-2019). Approval of the vision was expected in 2020, but the municipal council did not approve because they felt not enough involved in the participative process.

\section{Analysis}

In this section, we analyze how the four different types of invited space are experienced by governments (4.1) and by citizens (4.2). In this analysis, we focus on the similar and different patterns between collaborative and top-down spaces, and between integrated and fragmented spaces.

\section{Invitational Character Experienced by Governments}

The four invited spaces show one striking similarity. In all cases, all respondents experienced that the ultimate decision on which CIs are welcomed is taken by governments, and in none of the cases, the government came to a fully "hands-off" approach. For instance, decisions on which initiatives to facilitate in the rural area of SchouwenDuiveland are taken by the municipality, as a manager explained: "Well, our rules have to prevail, otherwise quarrels between neighbors will arise and no one wants that." The municipal councilors of Rotterdam can reject a 
challenge at any moment of the process of Right to Challenge. This was reflected in policy documents but also expressed by municipal managers: "Well, in the end we determine the conditions that initiators have to abide by". Thus, although the different kinds of invited spaces aim to incite citizens to take over some of the tasks and responsibilities previously assigned to the government, the ultimate distribution of responsibilities and power remains unchanged. As an Oosterwold policy advisor explained this: "Internally, there is really the fear that everything will go completely wrong, when we make people themselves responsible." The project manager added: "When things go wrong [...] we will intervene. Whether citizens like it or not."

The fragmented invited spaces-water level resolution Zegveld and area development Oosterwold-are experienced by governments as efficient and a comfortable way to be more invitational. By setting a clear demarcation beforehand, therewith aligning CIs with the fragmented domain orientation of governmental organizations, civil servants want to come to an efficient process in which a CIs can be approved or rejected: "We give a permit and we check whether people adhere to our principles", the project manager of Oosterwold stated. However, some government officials ask themselves whether opportunities for innovative and clever combinations are missed because of such a fragmented approach: "I do wonder whether we miss opportunities with our [fragmented] approach, like opportunities to tackle climate issues more broadly" (councilor HDSR).

On this point, civil servants involved in more integrated spaces are enthusiastic about the new, innovative combinations that arise. As is expressed by a manager of Schouwen-Duiveland: "We call these initiatives 'exotic', they are more than welcome!" In Rotterdam, citizens mentioned in workshops to make a combination between unemployment and cleaning-up a marketplace. This is a combination that the government could not realize: "Now, new innovations, energy and opportunities arise" (manager Rotterdam). At the same time, these integrated invited spaces are also described in the interviews with civil servants as "complex, time-consuming and difficult to handle" (manager Schouwen-Duiveland), "a complex process" (manager Rotterdam) and "risky" (manager Rotterdam).

Finally, we found different ways in which public interests related to CIs are weighted. In collaborative invited spaces, the governments explicitly chose a collaborative approach to make citizens part of the complex decisionmaking process. Such a collaborative process results in mutual understanding for the decisions that have to be made during the implementation. As a HDSR manager explains: "This participative process will enhance support and therewith create better solutions." Additionally, the
Environmental Vision Schouwen-Duiveland creates a common framework for government and citizens, which is used by civil servants when they deal with initiatives: "Hopefully this will create broad support and thus more effective decision making" (manager SchouwenDuiveland).

In top-down invited spaces, such a common framework is lacking and civil servants can only refer to their own (top-down created) rules, which results in persistent discussions and struggles with initiators about the legitimacy and feasibility of these rules. This was experienced by the managers involved in the Right to Challenge Rotterdam: "Basically the system is very easy, but I think the actual process will be pretty complex." We found this also in the Oosterwold case. In the workshops, civil servants from the municipality and water board mentioned the difficulties they experience with working from a top-down framework with simple rules, while citizens beforehand do not realize the complexities of realizing collective services, like roads and sanitation.

\section{Invitational Character Experienced by Citizens}

When citizen respondents discussed the invitational character of invited spaces, they all started by emphasizing the change in attitude of governments they recognize. This is positively described in the interviews as a shift from "counterworking" to "cooperating" and from "closed" to "open-minded." This collaborative attitude positively influences the perceived invitational character of each discussed invited space.

A collaborative process of producing the invited space, contributes to this positive perception. In the case of Schouwen-Duiveland, citizen respondents mentioned that the collaborative process shows how the municipality is "not a bastion anymore, but is honestly interested in their citizens and open to what is happening in society." In similar vein, respondents said about the water level resolution that the collaborative process signifies the "increased accessibility of the water board" and "their willingness to deliberate and collaborate with ordinary citizens." Citizens explained that given this increased sense of accessibility and willingness to cooperate, they feel more welcome and supported to come up with initiatives.

Nevertheless, a collaborative process does not only have a positive effect on the perceived invitational character. Through being involved in the collaborative process, citizens become aware of the complexity of policy making and the many different, oftentimes conflicting, interests. As one of the respondents elaborated: "I'm not jealous on the water board, because they have to balance all these different interests in our community." A lack of transparency during the production process is a serious threat for the 
invitational character of the invited space: "During the meeting I felt like the water board kept its cards close to its chest. I wish they were more open and tell us honestly where they're heading at." Along similar lines, respondents said about Schouwen-Duiveland: "I think they [the municipality] have a hidden agenda." and "well, what happens with my input? How is it weighted against other ideas and other parties? This is like a black-box to me. It all happens behind closed doors."

This results in a distrust in the authorities and in particular in their ability to make fair decisions. If this balancing of interests was not clear during the process, citizens expect this to be no different once the invited space is in force. Given this, citizens are less inclined to start an initiative, since they feel insufficiently protected against arbitrary actions and abuses of power, like they mentioned in the interviews: "I think especially businesses will benefit from this space for initiatives, not citizens" and

"The [participative] process opens up opportunities for powerful and clever businesses, who know how to use their personal connections. This is a problem. It's favoritism. I would like to see that the municipality protects itself and its citizens better against these interests by setting clear rules."

This danger to the invitational character seems to be especially strong when it involves the collaborative production of an integrated invited space, like SchouwenDuiveland, since the complexity and clash of interests are more prominent when compared to a fragmented invited space.

The integrated character of invited spaces appears to invoke diverse reactions, as we saw in the cases of Schouwen-Duiveland and Right to Challenge Rotterdam. On the one hand, citizens depicted such a space as invitational, since the integrated quality corresponds with their initiatives that often have an integrated character as well: "We want to address all issues at once, like physical, social, safety, participation and health." Another initiator adds to that: "I appreciate the integrated character. It fits my plans. Letting go of sectoral policy plans enables a tailor-made approach and flexibility." Thus, respondents expect that an integrated invited space will make is easier for them to unfold initiatives, which stimulates them to actually start an initiative. However, the integrated nature of invited spaces is also negatively associated with vagueness about what the government actually wants and asks for.

Some respondents stated that they prefer a stricter predefined invited space, because a more precise scope gives them clarity about what kind of initiatives are welcomed, under what conditions, and how different interests are being balanced: "It's all very vague and therefore unrealistic. What does the municipality [of SchouwenDuiveland] want? They have to state clear preferences" and "at the moment it's just too fuzzy, multi-interpretable, it's all over the place. I'm afraid this will create arbitrariness." This idea is underscored by respondents in the fragmented cases of Oosterwold and Zegveld: It's pretty well-defined, so that's clear to me what they [the water board] want and don't want." Some people in the Oosterwold case even asked for more rules and demarcations.

We also found that the top-down dimension of the production of invited spaces matters. Initially, citizens experience the spaces top-down created by governments as invitational. They, for instance, appreciate the clear conditions by which the initiatives have to abide. Despite that, the perceived invitational character quickly changes once initiators have entered the invited space. Then, many additional rules, regulations and organizational issues come to the fore: "The municipality sets out all kinds of conditions. We don't want that. We want to follow our own methods." Instead of taking their hands-off and respecting the autonomy of initiators, governments seem to opt yet for a more authoritative role. For example, in the Oosterwold case, citizens felt confronted with a rather complex procedure to get a water permit. Regarding the Right to Challenge, initiators are displeased by the fact that they are fully dependent on the municipality for approval of their initiative, while the initiators are the only ones who bear the risks. This, among others, discourages initiators. It also makes them doubt whether the government is actually capable of facilitating the initiative and if they intrinsically want the initiative to succeed.

\section{Lessons from Cross-Case Analysis}

In Table 1, we summarize the similarities and differences in the invitational character, as experienced by governments and citizens, of the four studied invited spaces.

Across the cases of different invited spaces, we found some similarities. In all cases, governments struggle with keeping their hands-off from public services and public value created by CIs. Moreover, since governments ultimately demarcate the invited space, the existing distribution of responsibilities and power between government and citizens does not change: the government eventually decides what initiatives citizens can develop or not. Nevertheless, another similarity is a change in governmental attitude that citizens in all cases experienced. This change is valued positively. So, despite the reproduction of dominant power structures, citizens feel more welcomed to develop CIs. Thus, it seems that a perceived change in attitude of governments might be of greater importance than a structural change in actual role and power division. 
Table 1 Summary of cross-case analysis

\begin{tabular}{|c|c|c|}
\hline & Invitational character experienced by governments & Invitational character experienced by citizens \\
\hline $\begin{array}{l}\text { Similarities between all } \\
\text { four types }\end{array}$ & $\begin{array}{l}\text { Governments are on crucial moments in the driver's } \\
\text { seat, and they do not use a fully hands-off approach } \\
\text { The distribution of responsibilities and power remains } \\
\text { unchanged }\end{array}$ & $\begin{array}{l}\text { The change of governmental attitude is recognized and } \\
\text { positively valued }\end{array}$ \\
\hline $\begin{array}{l}\text { Patterns and mechanisms } \\
\text { on axis collaborative } \\
\text { vs. top-down }\end{array}$ & $\begin{array}{l}\text { Top-down spaces are experienced as invitational at the } \\
\text { start, but thereafter discussion about the top-down } \\
\text { rules is continuously present } \\
\text { Collaborative spaces are experienced as complex, but } \\
\text { with less discussion because of a common framework }\end{array}$ & $\begin{array}{l}\text { Top-down spaces are experienced as very invitational at } \\
\text { the start, but during the implementation process the } \\
\text { disappointment increases } \\
\text { Collaborative spaces are experienced as invitational, but } \\
\text { only if the collaborative process is transparent and } \\
\text { inclusive }\end{array}$ \\
\hline $\begin{array}{l}\text { Patterns and mechanisms } \\
\text { on axis integrated vs. } \\
\text { fragmented }\end{array}$ & $\begin{array}{l}\text { Fragmented spaces are experienced as efficient and } \\
\text { clear, but one questions whether opportunities are } \\
\text { missed } \\
\text { Integrated spaces are experienced as fostering } \\
\text { innovation, but also as complex and time-consuming }\end{array}$ & $\begin{array}{l}\text { Fragmented spaces are experienced as accessible to many } \\
\text { citizens, because of the clear goals and boundaries } \\
\text { Integrated spaces are experienced as fitting with the } \\
\text { integrated ambitions of citizens, but the process is } \\
\text { complex and requires many skills }\end{array}$ \\
\hline
\end{tabular}

When having a closer look at the collaborative versus top-down axis, it appears that expectation management is crucial for the invitational character of top-down produced invited spaces. The two cases of top-down produced invited spaces are initially perceived as invitational by citizens because of the openness and clarity of the invitation. However, this quickly changes because realizing a CIs seems to be much more difficult than citizens expected beforehand. However, this quickly changes because realizing a CIs seems to be much more difficult than citizens expected beforehand, because the bureaucratic procedures are still quite intricate or because what has to be done by the initiators is quite complex. By some citizens, the "invitation" is even seen as a false pretention. Thus, expectation management from governments to citizens is needed to prevent disappointment, discontent and disillusion from arising once citizens come up with initiatives in practice.

However, the two studied collaborative invited spaces are not by definition experienced as invitational. For these spaces, transparency is a key element influencing the invitational character. A collaborative process makes it easier for governments to facilitate CIs and for citizens to organize themselves, since they can refer to a shared, commonly agreed-upon framework on these conditions. Nevertheless, this collaborative process is a very delicate and complex process, as is experienced by all participants. Without transparency, citizens suspect that professional stakeholders misuse the invited space, therewith obstructing opportunities for citizens. Therefore, transparency about the actors involved in the process and the balancing of interests during the process are critical to ensure the (perceived) invitational character of collaborative invited spaces.

The fragmented versus integrated axis shows that fragmented invited spaces are by governments and citizens positively associated with efficiency and clarity. Moreover, citizens see it as approachable and accessible (although the technical complexity in case of Oosterwold is still perceived as quite high). Integrated spaces, on the other hand, are by some citizens described as vague and complicated, and therefore only suitable for experienced initiators. Civil servants agree on this idea of an integrated space as complex and time consuming. However, they also recognize a positive side of the integrated character. They see it as innovative, prompting unconventional initiatives that cannot be designed by the government. Hence, we see a continuum here, on which governments can choose a position, depending on their objectives. When the public issue is clear and simple, and the ambition is to send an accessible invitation for CIs, a fragmented invited space is adequate. More complex issues that require innovative solutions demand a more integrated invited space.

\section{Reflection}

\section{Conclusions}

Our study shows that the way in which the invited space is settled matters. Based on the four cases we have studied, we summarize our findings in four lessons:

1. A perceived change in attitude of governments might be of a greater importance for citizens to feel invited than a structural change in actual role and power distributions.

2. Top-down invitations can create false promises and can result in an underestimation by citizens of the complexity of realizing CIs.

3. Collaboratively created invited spaces are perceived as invitational, on condition that governments are transparent about its inclusivity and balancing of interests. 
4. Fragmented and integrated invitational spaces could both be perceived as invitational. The former is well suited for CIs that undertake more monofunctional initiatives, while the latter fits complex issues requiring innovative solutions.

These lessons demonstrate that being invitational as governments is a process of constructing meaning in interaction with citizens. Merely creating invited spaces by removing or relaxing rules and structures (or creating new ones) is not sufficient to be perceived as invitational. It is in the experiential interactions between governments and citizens that an invitational character develops. This calls for increased attention of public administration scholars to the production of invited spaces as a "social production."

Interestingly, our findings are quite paradoxical. On the one hand, we witness a specification paradox. Well-delineated invited spaces are assumed to be not very open but are perceived as quite invitational because they give guidance and clarity to initiators: you know where you stand. At the other hand, there is a deliberation paradox. Constructing the invited space in a collaborative mode contributes to mutual understanding and a shared point of departure, but it also discourages people to undertake an initiative because of what they get to know about the government they are interacting with and the complexity of the "back-office." Understanding the consequences of this social production on subsequent actions and outcomes requires more focus on interactions, attitudes and meaning making, of both government officials and citizens, and the way they interpret one another's intentions and practices. As our study demonstrates, this is a valuable research approach to follow.

Although some authors suggest that invited spaces will replace "traditional" democratic principles like transparency and legitimacy (e.g., Aiken 2000; Sørensen 2016), our study shows that these democratic principles become even more important (see also Connelly 2011; Duijn and Van Popering-Verkerk 2019). For governments, the challenge is not only to develop these innovative invited spaces, but also to ensure the democratic legitimacy of these spaces in order to be perceived as invitational.

CIs are the product of the self-organizing capacity of society. They challenge governments when it comes to formulating public policies or providing public goods and services. CIs often invite themselves and ask for space to develop their own idea. Governments who want to guide these initiatives conform their own values and ambitions. Defining the invited space is often a reaction upon attempts of CIs to get space for their own initiative. The construction of the invited space can thus also be seen as an attempt from public authorities to reassert their authority in a "doit-yourself society" and thus as an intelligent form of metagovernance in a time of societal self-organization (Lister
2015). However, the ultimate shape of the invited space is also the result of how CIs react upon this attempt and thus of power interplay between state and society. The "intended" invited space differs from the ultimate realized space because citizens negotiate the boundaries of this space and do not automatically accept the conditions governments set to their initiative (Taylor 2007). Governments who do not want to discourage initiators and wish to minimize the risk of crowding out their intrinsic motivation have to be willing to cater to people who accuse the invited space as being too restrictive and control-focused (Blok, Fenger \& Van Buuren, under review).

\section{Contribution}

Our research contributes to the field in that it provides insight into how governments can evoke CIs, by unraveling how the social production of invited spaces influences the (perceived) invitational character of those spaces. From our research we learn that the rise of CIs asks for other ways of governance in which the demarcation of the invited space is crucial, but the process of demarcating and the way in which this process and its results are interpreted are even more important. Further research could disentangle how the production process and demarcation of invited spaces influence the invitational character in practice, e.g., what kind of CIs use the invited spaces, by whom are they initiated and on what topics?

In this study, we untangled the invitational character of invited spaces as perceived by citizens who are active in CIs or are interested in starting CIs. However, not all citizens are equally willing or able to initiate initiatives (Lowndes et al. 2006). How these citizens perceive the invitational character of invited spaces is a question that needs more attention. In a society characterized by active citizenship and a retreating government, these dynamics will become crucial to understand whether public goals will be realized or not.

\section{Compliance with Ethical Standards}

Conflict of interest The authors declare no conflict of interest.

Open Access This article is licensed under a Creative Commons Attribution 4.0 International License, which permits use, sharing, adaptation, distribution and reproduction in any medium or format, as long as you give appropriate credit to the original author(s) and the source, provide a link to the Creative Commons licence, and indicate if changes were made. The images or other third party material in this article are included in the article's Creative Commons licence, unless indicated otherwise in a credit line to the material. If material is not included in the article's Creative Commons licence and your intended use is not permitted by statutory regulation or exceeds the permitted use, you will need to obtain permission directly from the copyright holder. To view a copy of this licence, visit http://creativecommons. org/licenses/by/4.0/. 


\title{
Appendix 1
}

\author{
Overview of data collection per case
}

\begin{tabular}{|c|c|c|c|}
\hline Case & Desk study & Interviews & Observations/focus groups \\
\hline $\begin{array}{l}\text { Right to } \\
\text { Challenge } \\
\text { Rotterdam }\end{array}$ & $\begin{array}{l}\text { Policy documents and data } \\
\text { from internal monitoring } \\
\text { system }\end{array}$ & $\begin{array}{l}\text { Four team managers, one councilor and } \\
\text { secondary analysis of } 30 \text { interviews } \\
\text { (conducted by research department of } \\
\text { municipality) }\end{array}$ & $\begin{array}{l}13 \text { meetings of the team Right to Challenge } \\
\text { Rotterdam (2016-2018), one workshop } \\
\text { with citizens and civil servants and one } \\
\text { workshop with team managers }\end{array}$ \\
\hline $\begin{array}{l}\text { Water level } \\
\text { resolution } \\
\text { Zegveld HDSR }\end{array}$ & $\begin{array}{l}\text { Policy documents and } \\
\text { internal guides on } \\
\text { participation }\end{array}$ & $\begin{array}{l}\text { Three managers, one portfolio holder, two } \\
\text { citizens, one manager municipality, one } \\
\text { policy advisor }\end{array}$ & $\begin{array}{l}\text { Two participative meetings with citizens, } \\
\text { Three focus groups with managers }\end{array}$ \\
\hline $\begin{array}{l}\text { Environmental } \\
\text { Vision rural area } \\
\text { Schouwen- } \\
\text { Duiveland }\end{array}$ & $\begin{array}{l}\text { Policy documents and } \\
\text { internal documents on } \\
\text { process, planning and input }\end{array}$ & $\begin{array}{l}\text { Four team managers, two advisors, seven } \\
\text { citizens/entrepreneurs, four civil servants } \\
\text { other public organizations }\end{array}$ & $\begin{array}{l}\text { One public evening with presentation of the } \\
\text { vision, } \\
\text { Three focus groups with managers }\end{array}$ \\
\hline $\begin{array}{l}\text { Development } \\
\text { residential area } \\
\text { Oosterwold } \\
\text { (Almere) }\end{array}$ & $\begin{array}{l}\text { Policy documents and } \\
\text { information for initiators, } \\
\text { existing analyses, } \\
\text { newspaper articles }\end{array}$ & $\begin{array}{l}\text { Two members executive board regional } \\
\text { water authority, one member general } \\
\text { board, four civil servants, four initiators }\end{array}$ & $\begin{array}{l}\text { One focus group with involved policy } \\
\text { makers, one participative meeting with civil } \\
\text { servants of regional water authority }\end{array}$ \\
\hline
\end{tabular}

\section{References}

Aiken, M. (2000). Reflexive modernisation and the social economy. Studies in Social and Political Thought, 2, 21.

Aiken, M., \& Taylor, M. (2019). Civic action and volunteering: The changing space for popular engagement in England. VOLUNTAS: International Journal of Voluntary and Nonprofit Organizations, 30(1), 15-28.

Alford, J. (2002). Why do public-sector clients coproduce? Toward a contingency theory. Administration \& Society, 34(1), 32-56.

Bakker, J., Denters, B., Oude Vrielink, M., \& Klok, P.-J. (2012). Citizens' initiatives: How local governments fill their facilitative role. Local Government Studies, 38(4), 395-414.

Bang, H. P. (2009). "Yes we can": Identity politics and project politics for a late-modern world. Urban Research and Practice, 2(2), 1-21.

Bang, H. P., \& Sørensen, E. (1999). The Everyday maker: A new challenge to democratic governance. Administratibe Theory \& Praxis, 21(3), 325-341.

Barnes, M., Newman, J., \& Sullivan, H. (2004). Power, participation, and political renewal: Theoretical perspectives on public participation under New Labour in Britain. Social Politics, 11(2), 267-279.

Blok, S. N., Fenger, H. J. M., \& Van Buuren, M. W. (under review). Stimulating civic behavior? The paradoxes of incentivizing selforganization.

Blumer, H. (1954). What is wrong with social theory? American Sociological Review, 19(1), 3-10.

Boonstra, B., \& Boelens, L. (2011). Self-organization in urban development: Towards a new perspective on spatial planning. Urban Research \& Practice, 4(2), 99-122.

Bovaird, T. (2007). Beyond engagement and participation: User and community coproduction of public services. Public Administration Review, 67(5), 846-860.

Bryer, T. A. (2009). Explaining responsiveness in collaboration: Administrator and citizen role perspections. Public Administration Review, 69(2), 271-283.
Bryson, J. M., Crosby, B. C., \& Bloomberg, L. (2014). Public value governance: Moving beyond traditional public administration and the new public management. Public Administration Review, 74(4), 445-456.

Connelly, S. (2011). Constructing legitimacy in the new community governance. Urban Studies, 48, 929-946.

Corbin, J., \& Strauss, A. (2014). Basics of qualitative research. In Techniques and procedures for developing grounded theory. London: Sage.

Cornwall, A. (2002). Making spaces, changing places: situating participation in development. IDS Working Paper 170. Brighton: Institute of Development Studies.

Cornwall, A. (2004). Introduction: New democratic spaces? The politics and dynamics of institutionalized participation. IDS Bulletin, 35(2), 1-10.

Cozzolino, S., Buitelaar, E., Moroni, S., \& Sorel, N. (2017). Experimenting in urban self-organization. Framework-rules and emerging orders in Oosterwold (Almere, The Netherlands). Cosmos + Taxis, 4(2), 49-59.

Dekker, P. (2019). From pillarized active membership to populist active citizenship: The Dutch Do Democracy. VOLUNTAS: International Journal of Voluntary and Nonprofit Organizations, 30(1), 74-85.

Duijn, M., Van Buuren, A., Edelenbos, J., Van Popering-Verkerk, J., \& Van Meerkerk, I. (2019). Community-based initiatives in the Dutch water domain: the challenge of double helix alignment. International Journal of Water Resources Development. Online first.

Duijn, M., \& Van Popering-Verkerk, J. (2019). Integrated public value creation through community initiatives: Evidence from Dutch water management. Social Sciences, 2018, 7.

Eisenhardt, K. M. (1989). Building theories from case study research. Academy of Management Review, 14(4), 532-550.

Eriksson, K. (2012). Self-service society: Participative politics and new forms of governance. Public Administration, 90(3), 685-698.

Flick, U. (2007). Managing quality in qualitative research. Thousand Oaks: Sage. 
Fung, A. (2006). Varieties of participation in complex governance. Public Administration Review, 66(1), 66-75.

Gemeente Schouwen-Duiveland (2019). Omgevingsvisie Landelijk gebied Schouwen-Duiveland [in Dutch], Schouwen-Duiveland.

Gemeente Rotterdam (2015). Right to Challenge op zijn Rotterdams [in Dutch], Rotterdam.

Gemeente Rotterdam (2016). Right to Challenge: Plan van aanpak experimenteerperiode [in Dutch], Rotterdam.

Ghose, R. (2005). The complexities of citizen participation through collaborative governance. Space and Polity, 9(1), 61-75.

Glaser, B. G., \& Strauss, A. L. (1967). The discovery of grounded theory: strategies for qualitative research. Chicago: Aldine.

Gofen, A. (2015). Citizens' entrepreneurial role in public service provision. Public Management Review, 17(3), 404-424.

Igalla, M., Edelenbos, J., \& Van Meerkerk, I. (2019). Citizens in Action, what do they accomplish? A systematic literature review of citizen initiatives, their main characteristic, outcomes, and factors. VOLUNTAS: International Journal of Voluntary and Nonprofit Organizations, 30(5), 1176-1194.

Igalla, M., Edelenbos, J., \& Van Meerkerk, I. (2020). What explains the performance of community-based initiatives? Testing the impact of leadership, social capital, organizational capacity, and government support. Public Management Review, 22(4), 602-932.

Jones, P. (2003). Urban regeneration's poisoned chalice: Is there an impasse in (community) participation-based policy? Urban Studies, 40(3), 581-601.

Kewes, A., \& Munsch, C. (2019). Schould I stay or should I go? Engaging and disengaging experiences in welfare-sector volunteering. VOLUNTAS: International Journal of Voluntary and Nonprofit Organizations, 30(5), 1090-1103.

Kiser, L. L. (1984). Toward an institutional theory of citizen coproduction. Urban Affairs Review, 19(4), 485-510.

Kooiman, J. (1999). Social-political governance. Public Management, l(1), 67-92.

Korstenbroek, T., \& Smets, P. (2019). Developing the potential for change: Challenging power through social entrepreneurship in the Netherlands. VOLUNTAS: International Journal of Voluntary and Nonprofit Organizations, 30(3), 475-486.

Lefebvre, H. (1991). The social production of space. Oxford: Blackwell.

Lister, M. (2015). Citizens, doing it for themselves? The Big Society and government through community. Parliamentary Affairs, 68(2), 352-370.

Lowndes, V., Pratchett, L., \& Stoker, G. (2006). Diagnosing and remedying the failings of official participation schemes: The CLEAR Framework. Social Policy \& Society, 5(2), 281-291.
Lowndes, V., \& Sullivan, H. (2008). How low can you go? Rationales and challenges for neighbourhood governance. Public Administration, 86(1), 53-74.

McLennan, B. J. (2020). Conditions for effective coproduction in community-led disaster risk management. VOLUNTAS: International Journal of Voluntary and Nonprofit Organizations, 31, 316-332.

Meynhardt, T. (2009). Public value inside: What is public value creation? International Journal of Public Administration, 32(3), 192-219.

Nederhand, J., Bekkers, V., \& Voorberg, W. (2016). Self-organization and the role of government: How and why does self-organization evolve in the shadow of hierarchy? Public Management Review, 18(7), 1063-1084.

Patton, M. Q. (1987). How to use qualitative methods in evaluation. Newbury Park: Sage.

Rosol, M. (2012). Community volunteering as neoliberal strategy? Green space production in Berlin. Antipode, 44(1), 239-257.

Stake, R. (2013). Multiple case study analysis. New York, NY: Guilford.

Stoker, G. (2006). Public value management: A new narrative for networked governance? The American Review of Public Administration, 36(1), 41-57.

Taylor, M. (2007). Community participation in the real world: Opportunities and pitfalls in new governance spaces. Urban Studies, 4(2), 297-317.

Tellis, W. M. (1997). Introduction to case study. The Qualitative Report, 3, 1-14.

Hendriks, F., \& Tops, P. (2005). Everyday fixers as local heroes: A case study of vital interaction in urban governance. Local Government Studies, 31(4), 475-490.

Sørensen, E. (2016). Enhancing policy innovation by redesigning representative democracy. Policy \& Politics, 44(2), 155-170.

Specht, M. (2012). De Pragmatiek van Burgerparticipatie. Amsterdam: Vrije Universiteit.

Van Buuren, A. (2017). Vormgeven aan uitnodigend bestuur. Pleidooi voor een ontwerpgerichte bestuurskunde. Rotterdam: Erasmus Universiteit Rotterdam.

Voorberg, W., Bekkers, V., \& Tummers, L. (2015). A systematic review of co-creation and co-production: Embarking on the social innovation journey. Public Management Review, 17(9), 1333-1357.

Publisher's Note Springer Nature remains neutral with regard to jurisdictional claims in published maps and institutional affiliations. 